\title{
Product Placement: A Smart Marketing Tool Shifting a Company to the Next Competitive Level
}

\section{Kramolis Jan, Kopečková Martina}

\begin{abstract}
The primary aim of this paper was to discover connection between company's competitiveness and product placement as a marketing tool. The secondary aim was searching for the genesis of product placement. The mentioned issues are explained from the perspectives of three groups: TV studios experts, directors and producers, and other experts (media agencies and advertisers). The Czech Republic market where product placement can be registered is very small - only few television companies. The survey was conducted during years 2011 and 2012 in the Czech Republic. There is no directly measurable tool to tell us exact outputs. However, the results reveal: Marketers are sure that product placement is efficient. The product placement belongs to a longterm marketing field where the brand building is also included. On the basis of the ascertainments acquired by the survey, the basic links between product placement, long-term marketing, and competitiveness are explained in this paper.
\end{abstract}

Keywords: product placement, long-term marketing, brand building, competitiveness

JEL Classification: M31, M37

\section{INTRODUCTION}

Development of marketing competencies is particularly important in creating a competitive advantage. The following key decision areas are considered to be 'central' to strategic marketing management and to the development of marketing competencies. Firstly, the design of marketing mix (price, promotion, product, place) determines how the company will compete in these target markets. Secondly, marketing managers may have to choose between markets or market segments. The place where the company will compete is determined by the selection of a target market segment. Thirdly, advertising media selection referring to the prediction of the media to be used is another decision area within the marketing function. Fourthly, the design of marketing mix is a forecasting practice, by which marketing management attempts to predict the best available options (for each of the marketing mix elements, which are product, place, price and promotion) for a given mix or estimates that a specific set of assumptions will hold for a set of alternative mixes.

Positioning strategy is another marketing decision area where forecasting has a substantial contribution. The factors possibly affecting the next stage of the patterns (e.g. trend) that the product may follow in the PLC model can also be determined. Forecasting also helps managers determine the timing of entrance to the market. Moreover, sales prediction is also an area in which forecasting is utilized intensively. Predicting sales of a new product has a particular importance for management from strategic point of view. (Polat, 2008) 


\subsection{Long-term Strategy/Marketing}

Traditional marketing has focused on generating quicker profits. Nevertheless, key decision areas are a longer term strategy that is nowadays more likely to unlock new markets and establish communication with them under the terms of a company's vision. Long-term marketing plans are important and there are three main steps how to create them: carry out a risk review, create an opportunity review and create and consequently review a long-term marketing plan. (Drummond, 2012)

The key to long-term dominance is the product because the influence of marketing is gradually fading in the contrast to the product which always remains. Skibsted Ideation, design and branding agency (Skibsted and Hansen, 2011), even argue for a 1P (for Product), not 4P, approach to marketing. The researchers posit that in an increasingly transparent, digitally empowered economy, where everyone can potentially know everything, companies can no longer use the other three P's (Price, Promotion, and Place) to gain a long-term competitive advantage. The 1P idea consists in the theory that if you have an extraordinary product, customers will find it and buy it in a transparent economy. With today's speed of change, we are all fencing in the dark and we have to accept that yesterday's rules will not solve tomorrow's challenges.

If you appeals to "buy now," you will alienate a lot of potential customers. (Johnston, 2013)

Innovation is essential in order to obtain the extraordinary product. Innovation is present in several dimensions (Dinis, 2006):

- Product innovation resulting not only from the association of traditional techniques with innovative designs, but also from development of new applications for traditional products.

- Marketing innovation including market development and new marketing methods, e. g. product placement as a new marketing tool in the Czech Republic.

- Organizational innovation as the new arrangements and local links established on the basis of economic, social and cultural links.

\subsection{Evaluating Company Competitiveness}

According to Eftimoski and Milenkovski (2012) competitiveness could be defined as a set of institutions, policies and factors determining the productivity level of an economy. The determinants of competitiveness, in recent times, can be recognized in: knowledge, human capital, technological process, macroeconomic stability, etc.

The research team El-Diraby, Costa and Singh (2006) identified seven major factors for measuring company competitiveness. These major factors were arranged according to importance score of each factor (from the most important factor):

1. Track record

2. Corporate management

3. Supplier influence

4. Employees

5. Production capacity 
6. Customer bargaining power

7. Business environment

The track record is the most important factor for measuring company competitiveness. The track record factor can be defined in four areas:

- Company reputation - reputation within the segment with respect to customers and competitors alike.

- Company experience - length of time spent in the segment providing the same or a similar product.

- Customer satisfaction - level of customer satisfaction with the quality of service provided. Customer satisfaction is one of the important factors for the success of the company. (Neagu and Nicula, 2012)

- Relative market share and equity - the size of the existing segment share occupied by the company.

All these areas of the track record factor are closely interconnected to the ideas of the long term strategy of companies. Concerning the product (as 1P) and its innovation, the customer must receive information, they must want it and feel "I want to buy it now". Provided that we accept the fact "With today's speed of change, we are all fencing in the dark and have to accept that yesterday's rules will not solve tomorrow's challenges", it is necessary to find new ways of marketing communication. This article is focused on one of these new ways product placement. Product placement is still a very new and unusual form of marketing communication. These facts are critical for achievement of company competitiveness.

\subsection{Definition of Product Placement}

The definition of product placement has been changing over the years. One of the initial definitions comes from Balasubramanian (1994) who defines product placement as a paid message about the product communicated via intended but inconspicuous input of a branded product into a movie (or a TV program). Consequently, through product placement the viewers' belief in a product or their consumer behaviour can be influenced in a positive way. (Hudson and Hudson, 2006)

According to the American Federal Trade Commission, product placement is defined as a form of promotion in which branded products are placed into television programs by advertisers for a certain fee or other consideration. (Powell, Hardy, Hawkin and Macrury, 2009)

The Council for Radio and Television Broadcasting (CRTB) on its 11th session decided to issue a recommendation for TV broadcasting operators regarding how this new phenomenon should be introduced into broadcasting and especially how to mark it properly so that it is comprehensible for viewers.

Based on the Recommendation of the Council associated with the application of new legislation on product placement, which is fully published on the Council website, broadcasters are obliged to mark each program containing product placement with a pictogram. (Kalistová, 2010) 
In the last years some fundamental views of the business world have changed. From the intense focus on tangible goals of cost and time reduction, we see an increasing concern for the intangible values like the one of the complete user experience - that is how a person thinks a product defines her and makes her feel while using it. These are the factors which are more and more regarded as decisive for buying decisions. Therefore, the need for better information on non - technological development, such marketing and organizational innovation, is increasingly obvious. Referring to organizational innovation, it concerns the implementation of new methods involving significant changes in product design or packaging, product placement, promotion or pricing, changes appear also in the company business practice, workplace or external relations. (Lupeanu, Neagu and Neacsu, 2010)

As far as planning of product placement, recommending products or stimulation of the product sales and analyzing the customers' behaviour in shopping is concerned, the derived knowledge in a form of association rules may be used. In business, practitioners are interested in the relationship of these data. Association mining rules model data by finding the relationship of data in specific databases. (Phaichayon, Nittaya and Kittisak, 2012)

According to other authors (Eterovic and Donko, 2012) product placement can be classified as a category that is not a simple prediction. On the contrary, it is essential that product placement is based on more discoverable (learnable) psychological rules that can be potentially data mined. This statement is in contrast to another category in which promotion responses to trends, retail price elasticity, unit volume, season unit volume or even break a cannibalization rate, product similarity and in which economic value to the customer and competition price are in a direct correlation with the retail price. The later mentioned approach is regarded by the authors Eterovic and Donko as a more systematical and data oriented view of the factors that are possible to affect the price optimization procedure.

As a tool for achieving competitiveness, product placement in Europe has developed under different conditions than in the USA. The main tool for regulation of television in Europe used to be Television without Frontiers Directive decreed in 1989. Later in 1997 it was amended by the provisions regarding advertising, teleshopping and self-promotion of televisions. In 2007 the European Committee (European Union, 2007) presented its latest vision, now called the Audiovisual Media Service Directive (2007/65/EC).

Under the terms of the new Czech law effective from the 1st June 2010 (Czech Republic, 2010), product placement is translated as "placing of a product". From the perspective of the existing practice in the Czech cinematography and TV broadcasting it was common that various particular products or brands were displayed in audiovisual works. Discussions were held sometimes whether such display does or does not represent a surreptitious advertisement. The surreptitious advertisement is defined both in the Advertising Act (Czech Republic, 1995) and the Broadcasting Act (Czech Republic, 1991). Moreover, deceptive business practices are also covered in the Consumer Protection Act (Czech Republic, 1992), where certain definition of the surreptitious advertisement is incorporated as well. (Kůta, 2010) 


\subsection{Product Placement Classification}

Product placement can be classified according to various criteria. Product placement can be used in many audiovisual forms which nowadays affect customers. (Brennan, 2011; De Gregorio and Sung, 2010; Lehu, 2007; Přikrylová and Jahodová, 2010)

- In movies - probably the most significant utilization; among the most famous movies where product placement was used successfully belong James Bond or E.T.: The Extra-Terrestrial.

- In TV series and programs - Secret Millionaire, The Friends, American Idol.

- In novels and dramas - The Da Vinci Code.

- In songs - Humble Neighborhoods by Pink.

- In branded videogames - FIFA, London Taxi.

Some authors (Bueß, 2004; Lehu, 2007; Pálková, 2010; Přikrylová and Jahodová, 2010) distinguish types of product placement according to the way of its integration into a movie or a TV program.

- Dominant shot (apparent, on-set placement) - in an audiovisual work there is a direct shot on a product at the forefront so that the greater part of the TV screen is filled by the product and it is immediately identifiable by a viewer. Dominant shot can be further classified into integrated and non-integrated placement.

- Non-dominant shot (hidden, creative placement) - indirect shot on a product in the background so that the smaller part of the TV screen is filled by the product which is, therefore, a natural component of the shot and viewers are not being disturbed (not necessarily noticed by viewers).

- Verbal mention (audio placement) - the product is openly spoken in a work. By a verbal mention is meant not only mentioning the name of a brand, a product or service, but also making remarks on their essential features.

- Active product placement (audio-visual placement) - a product is used by some of the movie characters. For viewers the audio-visual placement combination is more noticeable and such placement can be mingled with the ordinary action of the program.

- Passive product placement (visual placement) - a product is either shown in a shot of a movie or a TV program, or placed in a virtual environment.

There is a number of other different classifications. Comparative product placement is discussed by D’Astous and Berada (2011). Product placement impacts on human behaviour and influence on the process of human behaviour and decision-making is observed by Ansons and Leboe (2011). From this perspective, cognitive (epistemic), affective (emotional) and conative (active, volitional) process of human behavior can be affected by product placement.

According to the form of payment for product placement, two types can be distinguished - paid and unpaid product placement. (Quinn, et al., 2010)

- Paid product placement - is regarded as either a provision of financial transactions paid by the producer or network, or fees charged to an advertisement agency for bargaining the placement 
- Unpaid product placement - is conceived as "added value" of placement integration. Within certain episode or scene an advertiser provides some prop, e.g. a car, free of charge, as a consideration for its free placement (a kind of barter).

\subsection{Conditions of Product Placement Utilization}

The importance of the product placement integration is confirmed by Sukki, Yung Kyun and Sujin (2011). Therefore, businessmen take a risk if they place too explicit products into visual media. Moreover, there can also be found other influential factors with a possible impact on the product placement efficiency - such as mood evoked by a program, correspondence of a brand with the story, brand familiarity, exposure duration or popularity and type of a program.

Consumers associate the movie world with their own one, find their aspiration to the product placed in a movie, which in turn influences their attitudes and consumption patterns. Prominent placement draws attention and can increase average consumer expenditures. However, increasing effects of other efficient factors, such as the actor's attitude to the product and connection to the plot of the story, have lower efficiency, because consumers are aware that such placement is paid. (Srivastava, 2011)

However, the most important is the claim of Williams, Petrosky, Hernandez and Page (2011) and Lindström (2009). They claim that if product placement is not sensibly embedded into a story, it is ineffective in the end and the investment of a company was useless. Conversely, if the product placement is used properly, the viewer's eye contact with the product is combined with a product information flow towards the viewer. Due to interactivity of this process, the aim of attracting the customers' attention to the product is fulfilled very effectively.

The results of Karniouchina, Uslay and Erenburg (2011) indicate that overexposure of a brand in a single movie (measured by the number of occurrences with the main character) can be harmful. Many times intuitive, less intensive, fleeting placement of a product turned out to be preferable in comparison to repeated and potentially more expensive placement of a brand with main characters. This finding indicates that movies requiring a deep emotional involvement may not necessarily be the best platform for product placement (as could be expected), because it might be found intrusive.

With regard to the pricing strategy, the managers are recommended to integrate psychological component of a price into that strategy. The reason is that strong brands price reduction is perceived as suspicious. However, strong media support of a brand (with which product placement is associated) may be crucial for the buyer. They are then willing to pay any price, regardless the final price. (Asamoah and Chovancová, 2011)

Wilson and Till (2011) pioneered the study of two factors by which recalling of the product placement is potentially influenced: product placement valence (intensity and scope of effects) and a direct connection between an actor and a product. Although no statistically significant impact of product placement valence was discovered by these authors, they claim unambiguously that recalling of a product is strongly influenced by its connection with an actor. It should also be noted that although duration of a display on a screen is important, an effectiveness threshold may exist, behind which overexposure of many products on a screen may be less effective. It is 
caused by the fact that products placed this way get blended in the mind of a viewer who starts ignoring them, which results in lower efficiency of product placement.

Consumers' opinions on the ethics of product placement vary considerably across product categories, especially at ethically controversial products such as alcohol, cigarettes and weapons. (Williams, Petrosky, Hernandez and Page, 2011) Perception of the product placement ethics may also be influenced by gender division of society. Researches show that perception of product placement depends on gender, especially just as for ethically controversial products. Statistically significant difference in the two ethically problematic products is indicated by the results. Alcohol and weapons in movies are more accepted by men. Also cigarettes are of the same statistical trend as alcohol and weapons. However, their results regarding gender differences are lower. On the other hand, "healthy products" are more accepted by women. (Hudson and Hudson, 2006)

On the contrary, according to Matthes, Wirth, Schemer and Kissling (2011), there exist no researches proving differences between gender, age and intelligence. Even if someone manages to find such effects, the question still remains why certain segments of population can be targeted by product placement better. These authors claim that older people can be characterized as more easily suggestible by product placement than younger people. Moreover, evidence exists that men are less independent regarding the product placement influence than women.

\section{PROBLEM FORMULATION}

One of the survey's goals is to discover connection between company's competitiveness and product placement as a marketing tool. Based on available sources, it was revealed that this issue is not mentioned by authors of publications and articles. One of plenty of reasons is that this topic is interdisciplinary. While product placement is mentioned and discussed in the field of marketing, competitiveness of a company is mentioned especially in the field of finance and business economics. On the one hand, product placement can be classified as non-exact, socalled soft science, while competitiveness, on the other hand, is defined exactly by various ways of comparison and calculation using economic indicators of businesses and industries.

\section{METHODS USED}

The research consists of two main parts. In the first part of research done in the first half of year 2011, a method of fully-structured interview was used. It was designed by the authors of the paper based on the experience from their previous research. The inquiry covered all principal television organizations in the Czech Republic (TV NOVA, PRIMA, and Czech Television). Television advertising experts as well as experts from the Committee for Radio and Television Broadcasting were addressed. Due to narrowness of Czech market, a structured interview with the experts in film, series, sitcom and television program making has been chosen as the most suitable tool for the investigation of these issues. The primary aim was to investigate product placement effectiveness to influence company competitiveness and consider links to long-term marketing, even genesis of product placement. This was done by means of guided interview, during which the individual main points of the questions were noted in questionnaires and, at the 
same time, recorded on the voice recorder for the purpose of a subsequent transcription of full answers that were entered into the database of results. The secondary aim was to investigate the expert view of product placement saturation in Czech audiovisual products.

In the second part of the research, the results were analyzed using quantification and by means of seeking a mutual dependence. Structured interviews contained 12 open questions. The experts were divided into several categories with common features. In total, 24 interviewees from television organizations and other experts took part in the research. The results obtained were subjects to a statistical study.

The results were subjects of critical assessment and a synthesis with already discovered and published data (secondary data) was carried out.

As for successfulness of the queried respondents, the highest successfulness was achieved by the "face to face" method (personal recommendation). The investigated area is rather specific, especially due to low accessibility of the expert respondents. It is apparent that addressing via e-mail or phone leads mainly to failure. On the contrary, the best way to gain the respondent willing to go through a structured interview is through personal recommendation.

Due to this fact, every structured interview with a respondent was finished by thanks together with a query for other potential contact that could have been addressed. It was discovered that if respondents are contacted with mentioning the reference to the person from which the contact was obtained, the probability of successful realization of the structured interview is very high.

Two hypotheses were formulated as well, each of them being subject of research and contributing to search for a solution of the given issue.

$H_{1}:$ A relation exists between knowledge about product placement tool as a part of long-term marketing and the occupational structure of respondents.

$\mathrm{H}_{2}$ : The answer "Product placement is related to modern marketing" will be recorded in more than $60 \%$.

Both hypotheses were tested on the level of significance of $\alpha=0.05$. The H1 hypothesis was subject to the $\chi^{2}$ test of independence for a contingent table, using IBM SPSS Statistics software. Pvalue and Excel XLStatistics 5 program was used for statistical evaluation of the H2 hypothesis.

\subsection{Target group characteristics}

The table below shows the occupational structure of respondents who participated in the structured interviews.

Tab. 1 - Target group characteristics. Source: author.

\begin{tabular}{|c|c|c|c|c|}
\hline & $\begin{array}{c}\text { TV studios } \\
\text { experts }\end{array}$ & $\begin{array}{c}\text { Directors and } \\
\text { producers }\end{array}$ & $\begin{array}{c}\text { Other experts } \\
\text { (media agencies } \\
\text { and advertisers) }\end{array}$ & Total \\
\hline Absolute share & 11 & 5 & 8 & 24 \\
\hline Relative share & $45.8 \%$ & $20.9 \%$ & $33.3 \%$ & $100 \%$ \\
\hline
\end{tabular}


The table above indicates that TV studios were largely represented (45.8\%), followed by specialists in the investigated area $(33.3 \%)$. The lowest share in the respondent structure is represented by producers and directors $(20.9 \%)$. It was intended that all three areas are balanced and represented sufficiently. Higher difference between the group of TV studios and the group of producers and directors can be found acceptable.

\section{PROBLEM SOLUTION}

The current state of the product placement influence on company competitiveness and links to long-term marketing on the Czech market are characterized by the following statements. In the case of a majority consensus, the data are quantified by a relative indicator and supplemented by important findings in the form of a comment. In the case of fragmentation of answers, only the most important findings in the surveyed area are listed.

Due to the fact that product placement as a part of marketing belongs to so-called "soft sciences", specific approach needed to be utilised in search for a solution of the investigated issue. An indirect method was chosen for investigation of a phenomenon that product placement as a smart marketing tool impacts on competitiveness of business. In the first phase, the influence of product placement on long-marketing was investigated. In today's world it is an indisputable fact that long-term marketing represents one of the basic issues that needs to be addressed if a company wants to be competitive in the long run.

\subsection{Product Placement Tool as Part of Long-term Marketing}

The above mentioned question was intended to investigate awareness and especially attitude of respondents to the product placement tool as a part of long-term marketing. The answers were evaluated and categorised into four groups. Vast majority of the answers belonged unambiguously to one of these. Categories of "Yes, we believe and we don't care about effectiveness" and "Sometimes, but without proof" are very similar. Respondents in the first category believe partially, but are not completely sure, that quantitative proofs exist. Respondents in the second group believe that quantitative proofs exist, but they do not need them for their decision making process because investment into product placement is found to be an additional tool of integrated marketing communication, the efficiency of which is does not need to be measured separately. These data have not been quantified deliberately, since their interpretation may be arguable. To illustrate the situation, the approximate distribution of opinions is showed in the following chart. 


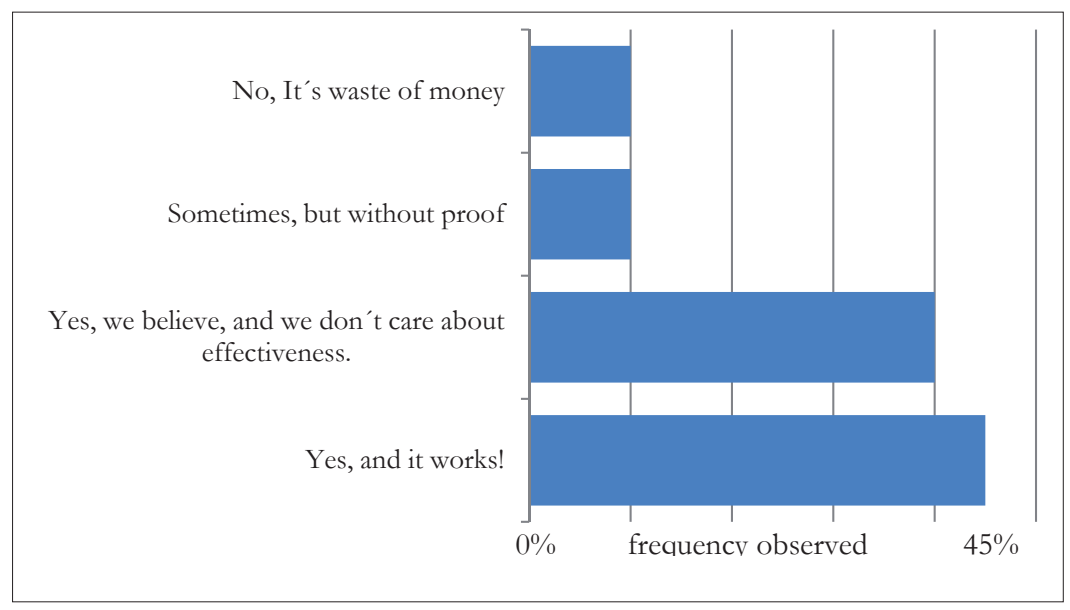

Fig. 1 -Product placement tool as a part of long-term marketing. Source: author.

Fig. 1 above indicates that two first categories (No, It's waste of money; Sometimes, but without proof) are even. However, in comparison to the other two categories, they really have only minority share. The following two categories are far more interesting. Majority of respondents are convinced that product placement as a part of long-term marketing works. The second most common opinion is also "yes". In this case respondents consider the way of measuring efficiency of the tool. However, at the same time they realise that for their purposes it is not necessary for the effect to be concretely measured and they are aware of the fact that marketing is a soft science. Needless to say that experts know about the effects of long-term marketing and its positive influence on competitiveness of a business. Relative ratios of the investigated area are stated in the following Tab. 2.

Tab. 2 - Knowledge about product placement tool as a part of long-term marketing. Source: author.

\begin{tabular}{|l|c|}
\hline \multicolumn{2}{|c|}{ Knowledge about product placement tool as a part of long-term marketing } \\
\hline Findings & Relative share (\%) \\
\hline Yes, and it works! & 42,857 \\
\hline Yes, we believe, and we don't care about effectiveness & 38,095 \\
\hline Sometimes, but without proof & 9,523 \\
\hline No, it's waste of money & 9,523 \\
\hline TOTAL & 100 \\
\hline
\end{tabular}

$\mathrm{H}_{1}$ hypothesis was related to this question.

$H_{1}:$ A relation exists between knowledge about product placement tool as a part of long-term marketing and the occupational structure of respondents. 
The respondents' answers and their mutual relation are pictured in the following contingent table.

Tab. 3 - Dependence of knowledge about product placement tool as a part of long-term marketing on the occupational structure of respondents. Source: author.

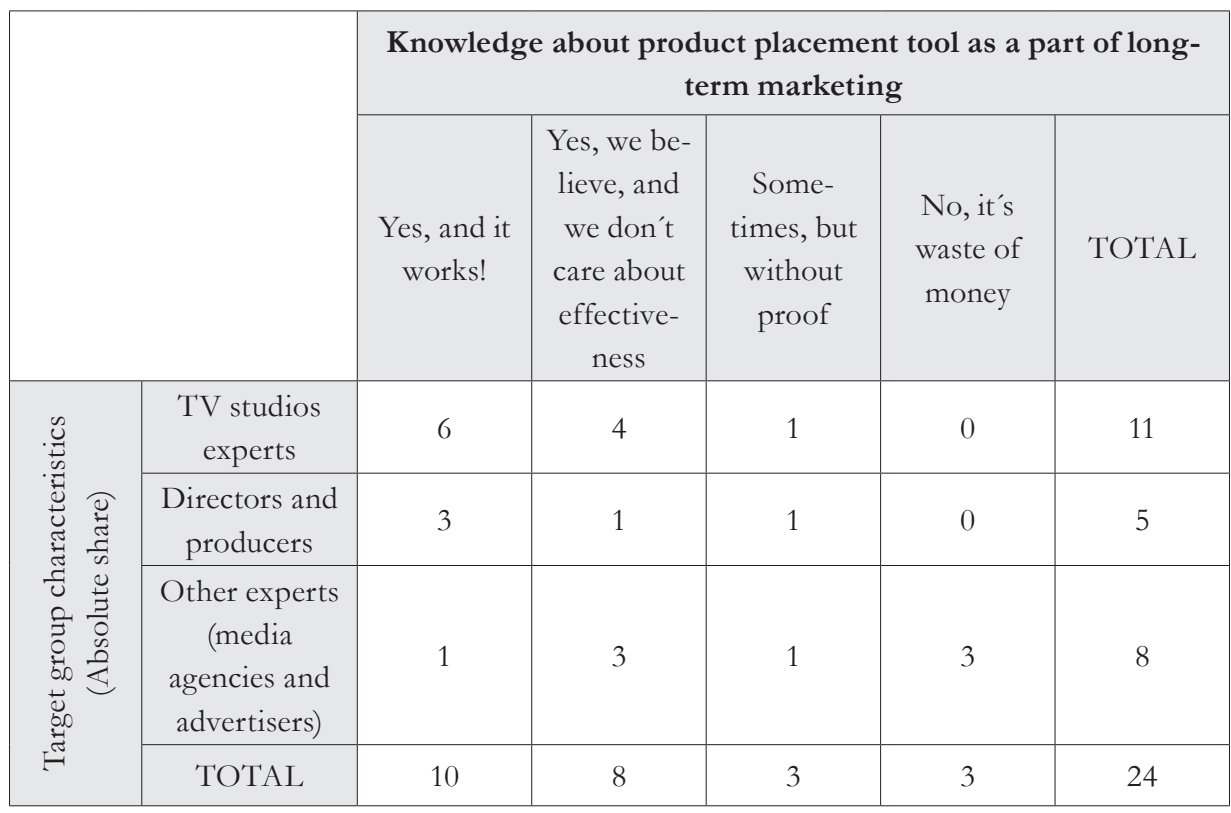

After the calculated value of the tested criterion $\chi^{2}=9,145$ was compared to the critical value of $\chi_{0,05}^{2}(6)=12,592$, it was found out that the calculated value was lower. Therefore, the null hypothesis was accepted. The null hypothesis $\mathrm{H}_{0}$, i.e. the opposite one to the formulated hypothesis $\mathrm{H} 1$, as well as the result of this test, says that there is no statistically confirmable relation between knowledge about product placement tool as a part of long-term marketing and the occupational structure of respondents.

\subsection{Product Placement as New Marketing Tool vs. only New Labeled Tool in Market- ing Theory (searching for genesis of product placement and its link to company competiveness)}

The vast majority of the subject examined (90\%) takes a positive attitude towards this tool. A neutral attitude could be interpreted as having some knowledge about this tool without a subjective assessment of an attitude. The results of the survey showed that nobody has stated they are not familiar with the term "product placement". This fact could be attributed to the information activities of the Czech media in the half of year 2010, when an amendment to the Act No. 231/2001 on Operation of Radio and Television Broadcasting (Czech Republic, 2001) regarding product placement was being discussed in media across the country. 


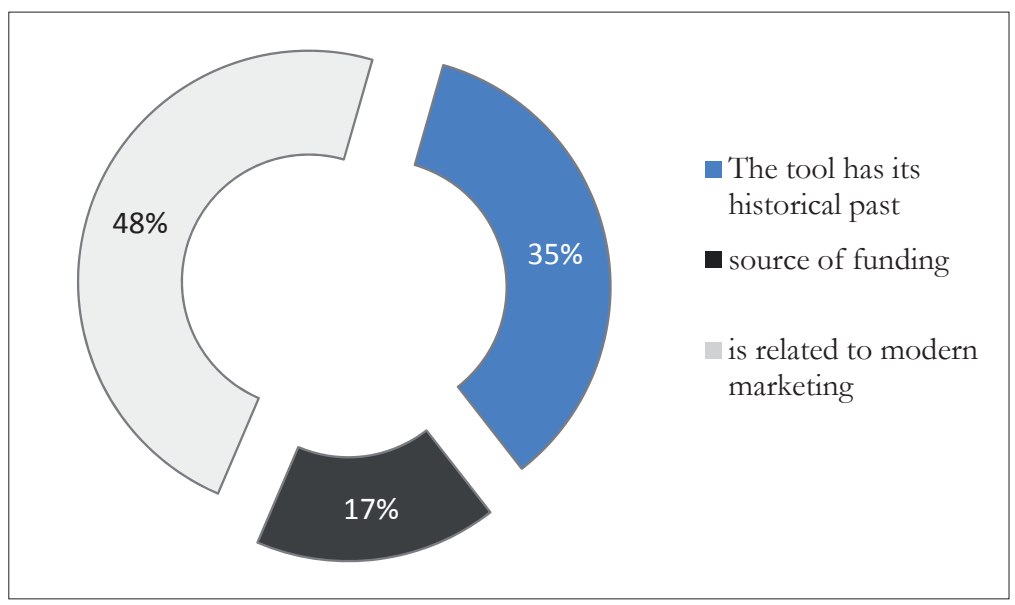

Fig. 2 - The term of product placement has most frequently been associated with three areas. Source: author.

The term of product placement has most frequently been associated with three areas:

1. The tool has its historical past, it is a few decades old and it has been developed the whole time (35\%). Therefore, it is merely a new name for an old tool.

2. In film, series and sitcom production, product placement represents an often left out source of funding $(17 \%)$.

3. Product placement is related to modern marketing or it represents a modern marketing tool $(48 \%)$.

It can therefore be said that all of the selected subjects examined know this marketing tool. To what extent they are familiar with the tool was investigated by means of following questions.

This question is related to the second hypothesis formulated for the purposes of this research.

$\mathrm{H}_{2}$ : The answer "Product placement is related to modern marketing" will be recorded in more than $60 \%$.

Taking into consideration that p-value was calculated at 0.007153 and thus is lower than the tested criterion $\alpha$, null hypothesis $\mathrm{H}_{0}$, i.e. the alternative one to $\mathrm{H}_{1}$ hypothesis, is statistically confirmed. It means that hypothesis $\mathrm{H}_{1}$ was not statistically confirmed and it can be concluded that less than $60 \%$ of respondents find product placement to be related to modern marketing.

What do we know about the "the tool has its historical past" part? We also talk about genesis of product placement when this tool, just as an array of other marketing and management terms, originated as a new name given to a set of existing tools. Nowadays, for example, terms taken over from English language such as "event, guerilla, WOM, viral, direct, etc." emerge in the Czech marketing environment.

\subsection{Effectiveness vs. Competitiveness}

As a part of inquiring respondents we also tried to define how it is with measurability of product placement effectiveness. Since this part was difficult to quantify, it was decided that descriptive definition would be used. 
Most of respondents are convinced that the extent of effectiveness and impact of product placement is measured by its ordering party and that it has its own ways. Most frequently familiarity with a brand or a product is measured, as well as direct effect on the sales volume. In some cases analyses of websites visitors and investigation of changes in websites turnout are utilised. A smaller proportion of respondents answered that it is very difficult to measure impacts of product placement concretely and especially that its exact quantification is impossible. Only around one of ten respondents has no idea whether product placement effects are being investigated and thinks that companies take advantage of product placement because they trust it themselves or have been persuaded to trust by a dealer. These ordering parties have neither time, nor money to measure concrete effects and impacts of product placement.

To sum up the results of the above mentioned question, they follow that if the product placement impacts are measured, one can be sure that influence on the company's competitiveness can be demonstrated. Whether this influence is positive or negative depends on many parameters which can occur in the long run. For that matter the relation to long-term marketing should not be omitted.

\section{CONCLUSION AND DISCUSSION}

Based on the learnt data and investigation of individual answers which were consistent in many ways, relation between product placement and competitiveness of a business can be found. If overall effort to achieve higher competitiveness is purified solely to a marketing factor, the following facts should be firstly taken into consideration:

1. Product placement is a part of long-term marketing

2. Product placement is one of above-the-line marketing tools

3. Product placement is a part of brand building

Long-term effects of the tool are a part of company's long-term strategy and of achieving better position on the market or directly increasing its market share. In the next phase, the link to company's competitiveness can be considered:

1. Long-term marketing directly impacts competitiveness of a company

2. Brand building encourages competitiveness of a company, especially by differentiating it from competitors

Synthesising these pieces of knowledge, the following figure no. 3 was constructed, depicting indirect relation between product placement and competitiveness of a company. Interconnectors as long-term marketing and brand building represent an integral part of the figure. No relation between product placement and competitiveness would be found without these. 


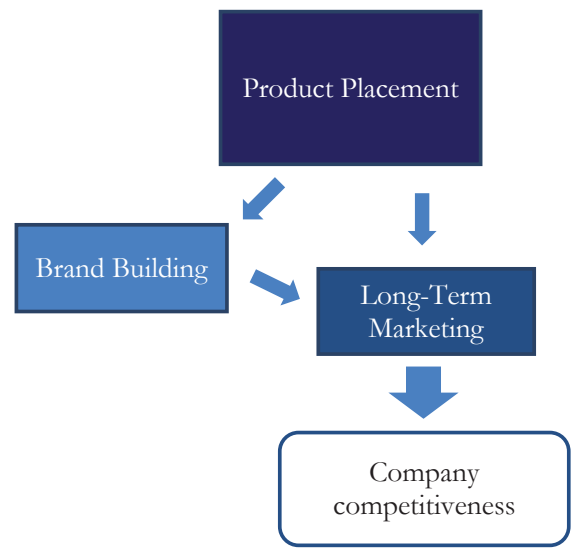

Fig. 3 - Product Placement influence on company competitiveness. Source: author.

Although not having been measured directly, it was confirmed by the research that experts do not need directly measurable data. Just as with other specific tools, they believe, and are strongly convinced, that this part impacts on competitiveness through long-term marketing. However, there are also other important components, especially:

- Integrated marketing communication,

- Elaborated marketing strategy including a long-term plan in line with a company's vision

If this tool is not used in line with the above listed principles, it can be concluded that its impact on company's competitiveness will be negligible. Product placement is very specific modern marketing tool and its utilisation is very limited and specific and serves for "illustration" of the overall image of a company or a brand. Since product placement is very expensive tool from the financial perspective, decision about its utilisation needs to be considered consistently. If misused, large amount of funds are wasted with zero effects.

If a company wants to be competitive and one step ahead of its competitors, long-term marketing and brand represent one of critical marketing areas that cannot be neglected.

\section{Acknowledgment}

This work was supported by IGA (Internal Grant Agency - Faculty of Economics and Management) Project Nr. IGA/53/FaME/11A.

\section{References}

1. Ansons, T., \& Leboe, J. (2011). The Nonanalytic Influence of Memory on Product Placement Consequences. Advances in Consumer Research - North American Conference Proceedings, 39, 547-548.

2. Asamoah, E. S., \& Chovancová, M. (2011). The Influence of Price Endings on Consumer Behavior: An Application of the Psychology of Perception. Acta Universitatis Agriculturae et Silviculturae Mendeleianae Brunensis, 59(7), 29-38. 
3. Balasubramanian, S. K. (1994). Beyond Advertising and Publicity: Hybrid Messages and Public Policy Issues. Journal of Advertising, 23(4), 29-46. http://dx.doi.org/10.1080/00913367 .1943 .10673457

4. Brennan, D. (2011). Getting closer to television content - The advertiser benefits. Journal of Sponsorship, 4(2), 145-154.

5. Bueß, J. (2004). Product placement: the analysis of a marketing communication instrument. Hamburg: Diplomica.

6. Czech Republic (1991). Act No. 468/1991 Coll., of 30 October, on the Operation of Radio and Television Broadcasts. Collection of Acts of the Czech Republic, 91, 2266-2273. Retrieved from http://aplikace.mvcr.cz/sbirka-zakonu/ViewFile.aspx?type=c\&id=2503

7. Czech Republic (1992). Act No. 634/1992 Coll., of 16 December, on Consumer Protection. Collection of Acts of the Czech Republic, 130, 3811-3816. Retrieved from http://aplikace.mvcr. $\mathrm{cz} /$ sbirka-zakonu/ViewFile.aspx?type $=$ c\&id $=2653$

8. Czech Republic (1995). Act No. 40/1995 Coll., of 9 February, on Regulation of Advertisement and Changes and Amendments of the Act No. 468/1991 Coll., on Operation of Sound and Television Broadcasting, as amended by later regulations. Collection of Acts of the Czech Republic, 8, 467-469. Retrieved from http://aplikace.mvcr.cz/sbirkazakonu/ViewFile.aspx?type $=\mathrm{c} \& \mathrm{id}=2819$

9. Czech Republic (2001). Act. No. 231/2001 Coll., of 4 July, on Operation of Radio and Television Broadcasting. Collection of Acts of the Czech Republic, 87, 5037-5068. Retrieved from http://aplikace.mvcr.cz/sbirka-zakonu/SearchResult.aspx?q=231/ 2001\&typeLaw=zakon\&what=Cislo_zakona_smlouvy

10. Czech Republic (2010). Act No. 132/2010 Coll., of 11 May, on Audio-visual Media Services on Demand and on the Amendment to some other Laws (Act on Audio-visual Media Services On-demand). Collection of Acts of the Caech Republic, 47, 1721-1744. Retrieved from http://aplikace.mvcr.cz/sbirka-zakonu/ViewFile.aspx?type $=$ c\&id $=5707$

11. D’Astous, A., \& Berrada, C. (2011). Communication Strategies to Enhance the Effectiveness of Product Placement in Movies: The Case of Comparative Appeal. International Journal of Arts Management, 14(1), 45-55.

12. De Gregorio, F., \& Sung, Y. (2010). Understanding attitudes toward and behaviors in response to product placement: A consumer socialization framework. Journal of Advertising, 39(1), 83-96. http://dx.doi.org/10.2753/JOA0091-3367390106

13. Dinis, A. (2006). Marketing and Innovation: Useful Tools for Competitiveness in Rural and Peripheral Areas. European Planning Studies, 14(1), 9-22. http://dx.doi.org/10.1080/09654310 500339083

14. Drummond, J. (2012). Long-term marketing: a new paradigm shift. Guardian News and Media Limited. Retrieved from http://www.guardian.co.uk/sustainable-business/blog/ marketing-long-term-paradigm-new-markets

15. Eftimoski, D., \& Milenkovski B. (2012). The Knowledge Competitiveness of Macedonian Economy - Comparative Analysis. Journal of Competitiveness, 4(3), 122-135. http://dx.doi. org/10.7441/joc.2012.03.09 
16. El-Diraby, T. E., Costa, J., \& Singh, S. (2006). How do contractors evaluate company competitiveness and market attractiveness? The case of Toronto contractors. Canadian Journal of Civil Engineering, 33(5), 596-608. http://dx.doi.org/10.1139/106-017

17. Eterovic, T., \& Donko, D. (2012). Price Decision Support System Security - Features and Online Prediction Defense in Adversarial Environment. Latest Trends in Applied Informatics and Computing, Barcelona, 184-188.

18. European Union (2007). Directive 2007/65/EC of the European Parliament and of the Council, of 11 December, on amending Council Directive 89/552/EEC on the coordination of certain provisions laid down by law, regulation or administrative action in Member States concerning the pursuit of television broadcasting activities. Official Journal of the European Union, 332, 27-45. Retrieved from http://eur-lex.europa.eu/LexUriServ/ LexUriServ.do?uri=OJ:L:2007:332:0027:0045:CS:PDF

19. Hudson, S., \& Hudson, D. (2006). Branded Entertainment: A New Advertising Technique or Product Placement in Disguise? Journal of Marketing Management, 22(5/6), 489-504. http:// dx.doi.org/10.1362/026725706777978703

20. Johnston, K. (2013). What Is Long-Term Marketing? Hearst Communications. Retrieved from http://smallbusiness.chron.com/longterm-marketing-26364.html.

21. Kalistová, K. (2010). Umistèní produktu (Product Placement). Rada pro rozhlasové a televizní vysílání (The Council for Radio and Television Broadcasting). Retrieved from http://www. rrtv.cz/files/pdf/Product $\% 20$ placement_na $\% 20$ web_pro $\% 20$ div $\%$ C3\%A1ky.pdf.

22. Karniouchina, E., Uslay, C., \& Erenburg, G. (2011). Do Marketing Media Have Life Cycles? The Case of Product Placement in Movies. Journal of Marketing, 75(3), 27-48. http://dx.doi. org/10.1509/jmkg.75.3.27

23. Kůta, P. (2010). Product placement se konečně dočká právní úpravy (Product placement is in legislating). Epravo.č Retrieved from http://www.epravo.cz/top/clanky/productplacement-sekonecne-docka-pravni-upravy-60969.html.

24. Lehu, J.-M. (2007). Branded Entertainment: Product Placement \& Brand Strategy in the Entertainment Business. London: Kogan Page.

25. Lindström, M. (2009). Buylogy: Truth and Lies About Why We Buy. New York: Crown Business

26. Lupeanu, M., Neagu, C., \& Neacsu, A. (2010). Current Trends in Product Development. In. Proceedings of the 4th European Computing Conference, Bucharest (pp. 94-99). USA: World Scientific and Engineering Academy and Society (WSEAS).

27. Matthes, J., Wirth, W., Schemer, C., \& Kissling, A. (2011). I See What You Don't See. Journal of Advertising, 40(4), 85-100. http://dx.doi.org/10.2753/JOA0091-3367400406

28. Neagu, E. R., \& Nicula, V. (2012). Influence of Organizational Culture on Company Performance. Revista Academiei Forțelor Terestre, 4(68), 420-424.

29. Pálková, M. (2010). Product placement: Basic characteristic and main rules for using in Czech TV and TV Barrandov. MediaMaster. Retrieved from http://www.media-master.cz/files/ Martin/PP/Pravidla\%20pro\%20Product\%20Placement_2010.pdf.

30. Phaichayon, K. Y., Nittaya, K., \& Kittisak, K. (2012). Association Rule Discovery with Constraint Logic Programming. In. Latest Advances in Systems Science and Computational Intelligence (pp. 135-140). Singapore. 
31. Polat, C. (2008). Forecasting as a Strategic Decision-Making Tool: A Review and Discussion with Emphasis on Marketing Management. European Journal of Scientific Research, 20(2), 419-442.

32. Powell, H., Hardy, J., Hawkin, S., \& Macrury, I. (2009). The Advertising Handbook. London: Routledge.

33. Přikrylová, J., \& Jahodová, H. (2010). Moderni marketingová komunikace (Modern marketing communication). Prague: Grada.

34. Quinn, P. et al. (2010). Global Branded Entertainment Marketing Forecast 2010-2014: Executive Summary. PQMedia.com. Retrieved from http://www.pqmedia.com/brandedentertainmentf orecast2010.html\# execSummary.

35. Skibsted, J. M., \& Hansen, R. B. (2011). The Key To Long-Term Dominance? Marketing Fades, But Product Always Lasts. Mansueto Ventures. Retrieved from http://www.fastcodesign. com/1665431/the-key-to-long-term-dominance-marketing-fades-but-product-always-lasts.

36. Srivastava, R. (2011). Brand Placement Strategy in a Film Song and Its Impact on Brand's Image. IUP Journal of Brand Management, 8(2), 19-30.

37. Sukki, Y., Yung Kyun, C., \& Sujin, S. (2011). When Intrusive Can Be Likeable. Journal of Advertising, 40(2), 63-75. http://dx.doi.org/10.2753/JOA0091-3367400205

38. Williams, K., Petrosky, A., Hernandez, E., \& Page, J. (2011). Product placement effectiveness: revisited and renewed. Journal of Management \& Marketing Research, 7, 1-24.

39. Wilson, R., \& Till, B. (2011). Product placement in movies and on Broadway. International Journal of Advertising, 30(3), 373-398. http://dx.doi.org/10.2501/IJA-30-3-373-398

\section{Contact information}

Mgr. Jan Kramoliš, Ph.D.

Tomas Bata University in Zlin, Faculty of Management and Economics

Mostni 5139, 76001 Zlin, Czech Republic

Email:kramolis@fame.utb.cz.

Ing. Martina Kopečková

Tomas Bata University in Zlin, Faculty of Management and Economics

Mostni 5139, 76001 Zlin, Czech Republic

Email:kopeckova@fame.utb.cz. 